\title{
Penggunaan Metode Eksperimen dapat Meningkatkan Pemahaman Siswa Tentang Konsep Pesawat Sederhana pada Mata Pelajaran IPA SDN. No. 033/XI Tanjung Muda Tahun 2016/2017
}

\author{
Emi Nofrida ${ }^{1}$ \\ Guru di SDN. No. 033/XI Tanjung Muda ${ }^{1}$ \\ Kecamatan Hamparan Rawang, Kota Sungai Penuh, Provinsi Jambi
}

\begin{abstract}
Science learning in elementary schools is the important foundation in instilling scientific knowledge, skills, and attitudes. However, one of the problems faced by teachers in elementary schools is that students have difficulty understanding concepts in science subjects which result in low learning outcomes. This study aims to improve students' understanding of the concept of simple aircraft in science subjects by using experimental methods. The research is a classroom action research involving 20 students of fifth grade year 2016/2017 in SDN. No. 033/XI Tanjung Muda, Hamparan Rawang Subdistrict, Sungai Penuh City, Jambi Province. This research was conducted from January to May 2017. This research was conducted in two cycles and each cycle consisted of two meetings with four activities namely planning, implementation, observation, and reflection. Understanding of concepts is measured by student activity in class and learning outcomes. Data was collected by tests and observations. Data was processed and analyzed by descriptive analysis and simple statistical test. The results showed that the use of experimental methods can improve the understanding of students about the concept of simple aircraft. The use of experimental methods increases students' activity and learning outcomes. Increased student learning activity seen from the increasing percentage of students who ask questions, working together in groups, able to conduct experiments independently, cleaning and storing tools and materials that have been used in the experiment, and deliver the results of experiments. The results showed that the mean grade increased from 47,5 (before action) to 60,5 (cycle I) and 75,0 (cycle II). The percentage of completed students in learning also increased from 45,0\% (before action) to 60,0\% (cycle I) and 85,0\% (cycle II). Thus, the experimental method can be an alternative in improving students' understanding of the concept in science subjects.
\end{abstract}

Keywords: elementary school students, experiments, learning activities, learning outcomes, science subject

\section{PENDAHULUAN}

Belajar merupakan suatu proses yang mengakibatkan adanya perubahan perilaku. Perubahan itu dapat terjadi dalam segi kognitif, psikomotor, dan afektif. Perubahan perilaku terjadi sebagai akibat dari latihan dan pengalaman. Hal ini diperkuat dengan pernyataan Djamarah (2011) yang mendefinisikan belajar sebagai serangkaian kegiatan jiwa raga untuk memperoleh suatu perubahan tingkah laku sebagai hasil dari pengalaman individu dalam interaksi dengan lingkungannya yang menyangkut kognitif, afektif, dan psikomotor. Perubahan yang disebabkan karena belajar itu bersifat relatif permanen, yang berarti perubahan itu akan bertahan dalam waktu yang relatif lama. Dilain pihak, perubahan tersebut tidak akan menetap terus menerus, hingga suatu waktu hal tersebut dapat berubah lagi sebagai akibat belajar.

Dalam proses belajar Ilmu Pengetahuan Alam (IPA) khususnya IPA di Sekolah Dasar, belajar seharusnya tidak hanya sekedar menerima informasi, mengingat, dan menghafal. Siswa diharapkan dapat memahami mengenai 
konsep yang telah dipelajari. Pemahaman tentang konsep memudahkan siswa untuk menerapkan konsep tersebut dalam kehidupan sehari-hari. Dengan demikian, guru tidak hanya bertugas untuk menyampaikan informasi pada siswa, tetapi juga bertugas untuk mengusahakan konsep yang telah diajarkan tertanam kuat dalam pikiran siswa.

Mata pelajaran IPA di Sekolah Dasar merupakan mata pelajaran yang bertanggung jawab untuk menanamkan pengetahuan, keterampilan, dan sikap ilmiah pada siswa. Untuk mencapai tujuan tersebut, guru perlu memberikan pengalaman belajar yang memadai untuk siswa melalui kegiatan pembelajaran. Rusmono (2012) mengartikan pembelajaran sebagai upaya untuk menciptakan suatu kondisi bagi terciptanya suatu kegiatan belajar yang memungkinkan siswa memperoleh pengalaman belajar yang memadai. Pembelajaran IPA harus mampu mengarahkan siswa untuk mencari tahu tentang alam secara sistematis. Hal ini dilakukan karena pembelajaran IPA sangat berperan dalam proses pendidikan dan juga perkembangan teknologi. IPA dapat membangkitkan minat dan kemampuan manusia dalam mengembangkan ilmu pengetahuan dan teknologi, serta pemahaman tentang alam semesta yang mempunyai banyak fakta yang belum terungkap dan masih bersifat rahasia sehingga hasil penemuannya dapat dikembangkan menjadi ilmu pengetahuan alam yang baru.

Keberhasilan pembelajaran khususnya keberhasilan dalam pembelajaran IPA dapat dicapai apabila masalah yang muncul dalam pembelajaran tersebut dapat dipecahkan. Guru kelas V di SDN. No.033/XI Tanjung Muda menemukan masalah dalam pembelajaran IPA. Masalah tersebut adalah siswa kurang memahami konsep yang telah diajarkan. Guru mencoba menelaah penyebab munculnya masalah tersebut. Hasil identifikasi masalah menunjukkan bahwa metode yang digunakan dalam pembelajaran kurang tepat. Metode yang digunakan adalah metode ceramah dan tanya jawab. Materi yang diajarkan dalam mata pelajaran IPA dinilai kurang cocok jika diajarkan dengan metode ceramah dan tanya jawab. Alasannya, metode ini akan mendorong pelaksanaan pembelajaran berpusat pada guru dan cenderung kurang melibatkan siswa secara aktif. Akibatnya, siswa lebih cenderung duduk diam, mendengarkan, mencatat, dan menghafal pengetahuan yang diberikan oleh guru. Hal ini berdampak pada hasil belajar siswa. Karena siswa tidak dilibatkan secara aktif maka siswa mudah lupa dengan materi yang sudah dipelajari sebelumnya. Selanjutnya, untuk menguatkan hasil pengamatan, guru melakukan tes penjajakan. Hasil tes penjajakan menunjukkan bahwa nilai rata-rata yang diperoleh 20 orang siswa pada mata pelajaran IPA di kelas V SDN. No. 033/XI Tanjung Muda adalah sebesar 47,5 dengan ketuntasan belajar sebesar $45,0 \%$. Hasil ini mengindikasikan bahwa hasil belajar siswa rendah yang mengindikasikan tujuan pembelajaran tidak tercapai dengan baik. Hal ini dapat terjadi karena pemahaman siswa tentang konsep masih rendah yang menyebabkan siswa kesulitan untuk menjawab soal yang berkaitan dengan konsep. Salah satu faktor yang menyebabkan rendahnya pemahaman konsep adalah penggunaan metode pembelajaran yang bersifat konvensional, hanya berupa ceramah dan tanya jawab. Padahal, materi IPA bersifat abstrak dan sulit. Dengan demikian, guru perlu mengganti metode pembelajaran yang disesuaikan dengan tujuan penelitian.

Metode pembelajaran merupakan cara melakukan atau menyajikan, menguraikan materi pembelajaran kepada siswa untuk mencapai tujuan (Yamin, 2007). Metode pembelajaran juga dapat diartikan sebagai cara yang berisi prosedur baku untuk melaksanakan kegiatan pembelajaran, khususnya kegiatan 
penyajian materi pelajaran kepada siswa (Suprihatiningrum, 2014). Metode dalam mengajar berperan sebagai alat untuk menciptakan proses pembelajaran antara siswa dan guru. Ada banyak jenis metode pembelajaran yang dapat dipilih oleh guru. Jenis dari metode pembelajaran yang dapat dipilih oleh guru adalah ceramah, latihan, diskusi dan tanya jawab, karyawisata, demonstrasi, sosiodrama dan bermain peran, eksperimen, dan proyek (Irham dan Wiyani, 2013). Setiap metode memiliki kelebihan dan kelemahan masing-masing.

Hasil penelitian sebelumnya menunjukkan bahwa ada beberapa metode/model pembelajaran yang dapat digunakan untuk meningkatkan hasil belajar siswa Sekolah Dasar pada mata pelajaran IPA, yaitu metode demonstrasi (Suak, Said, dan Paluin, 2016), metode explicit intstruction (Megawati, 2016), model pembelajaran kooperatif tipe Jigsaw (Rukmia), Model Kooperatif Tipe STAD (Adji, Rede, \& Mestawaty, 2016), penggunaan KIT IPA (Ambai, Said, dan Ratman, 2014), metode eksperimen (Asmawir, 2016; Rosilahwati, 2016; Habiby, 2016; Khotimah, 2015; Maria, 2014; Rahayu, 2013). Metode yang dianggap relevan dengan konsep yang akan diajarkan adalah metode eksperimen. Hasil penelitian sebelumnya menunjukkan bahwa metode eksperimen dapat meningkatkan hasil belajar siswa SD pada mata pelajaran IPA (Asmawir, 2016; Rosilahwati, 2016; Habiby, 2016; Khotimah, 2015; Maria, 2014; Rahayu, 2013). Hasil ini diperkuat juga dengan temuan Pranolo (2013) bahwa metode eksperimen berpengaruh signifikan positif terhadap hasil belajar siswa SD pada mata pelajaran IPA.

Berdasarkan pemaparan tersebut, penulis tertarik untuk melakukan penelitian yang berjudul "Penggunaan Metode Eksperimen untuk Meningkatkan Pemahaman Siswa tentang Konsep Pesawat Sederhana pada Mata Pelajaran Ilmu Pengetahuan Alam Kelas V SDN.
No. 033/XI Tanjung Muda Tahun 2016/2017'. Penelitian ini bertujuan untuk meningkatkan pemahaman siswa kelas V SDN. No. 033/XI Tanjung Muda Tahun 2016/2017 tentang konsep pesawat sederhana pada mata pelajaran Ilmu Pengetahuan Alam dengan menggunakan metode eksperimen.

\section{METODE PENELITIAN}

Penelitian ini merupakan penelitian tindakan kelas. Penelitian dilakukan di SDN. No. 033/XI Tanjung Muda, Kecamatan Hamparan Rawang, Kota Sungai Penuh, Provinsi Jambi. Kegiatan penelitian terdiri atas penyusunan proposal penelitian, pengumpulan data, pengolahan data, analisis data, dan penyusunan laporan. Penelitian dilakukan sejak bulan Januari hingga bulan Mei tahun 2017.

Subjek dalam penelitian ini adalah siswa kelas $\mathrm{V}$ semester genap tahun 2016/2017 di SDN. No. 033/XI Tanjung Muda, Kecamatan Hamparan Rawang, Kota Sungai Penuh, Provinsi Jambi. Jumlah subjek yang terlibat dalam penelitian ini adalah 20 orang siswa. Objek dalam penelitian ini adalah peningkatan pemahaman siswa kelas V SDN. No. 033/XI Tanjung Muda tentang konsep pesawat sederhana pada mata pelajaran IPA. Sub pokok bahasan yang akan dibahas adalah pengungkit, bidang miring, katrol, dan roda berporos.

Data yang dikumpulkan dalam penelitian tindakan kelas ini adalah data pemahaman tentang konsep yang dilihat dari aktivitas dan hasil belajar siswa pada mata pelajaran IPA. Aktivitas belajar diukur dengan evaluasi belajar jenis nontes. Evaluasi hasil belajar jenis nontes yang digunakan adalah pengamatan atau observasi. Observasi merupakan cara untuk menghimpun data atau bahan-bahan keterangan yang dilakukan dengan mengadakan pengamatan dan pencatatan secara sistematis terhadap fenomenafenomena yang sedang dijadikan sasaran pengamatan. Dalam penelitian ini, 
observasi dilakukan untuk mengamati tingkah laku siswa selama proses pembelajaran berlangsung. Observasi dilakukan untuk mengetahui keaktifan siswa dalam melakukan skenario pembelajaran. Hasil observasi digunakan untuk mengetahui proses pembelajarandan untuk memperbaiki kualitas pembelajaran.

Data hasil belajar dikumpulkan dengan evaluasi hasil belajar jenis tes. Evaluasi hasil belajar jenis tes merupakan cara untuk melakukan proses penilaian dalam bentuk tugas atau serangkaian tugas yang harus dikerjakan siswa atau sekelompok siswa sehingga menghasilkan suatu nilai yang menggambarkan prestasi siswa. Dalam penelitian ini, tes bertujuan untuk mengukur hasil belajar siswa dengan cara guru memberikan pertanyaanpertanyaan yang harus dijawab atau perintah-perintah yang harus dijalankan oleh siswa pada mata pelajaran IPA, khususnya pada materi pesawat sederhana. Tes yang diberikan berupa tes objektif. Setelah itu, guru memberikan penilaian terhadap hasil tes yang diperoleh siswa dengan cara menghitung nilai rata-rata kelas dan persentase ketuntasan belajar.

Penelitian tindakan kelas ini dilaksanakan dalam dua siklus yaitu siklus I dan siklus II. Setiap siklus dilakukan sebanyak dua kali pertemuan. Masingmasing siklus terdiri atas empat kegiatan, yaitu perencanaan, pelaksanakan, pengamatan, dan refleksi. Selanjutnya, data yang dikumpulkan diolah dan dianalisis. Analisis yang digunakan adalah analisis deskriptif dan uji statistik sederhana untuk mengetahui efektifitas dan tingkat keberhasilan suatu tindakan. Uji statistik sederhana digunakan untuk menghitung nilai rata-rata dan ketuntasan belajar siswa, baik sebelum diberikan tindakan maupun setelah diberikan tindakan (Siklus I dan Siklus II). Selanjutnya, nilai rata-rata dan persentase ketuntasan belajar siswa yang diperoleh dianalisis untuk mengetahui apakah tindakan yang diberikan berhasil atau tidak. Analisis dilakukan dengan cara membandingkan nilai rata-rata dan ketuntasan belajar yang diperoleh siswa sebelum dan sesudah tindakan.

Indikator keberhasilan dari penelitian tindakan kelas ini adalah peningkatan pemahaman tentang konsep pada siswa kelas V SDN. No. 033/XI Tanjung Muda pada mata pelajaran IPA yang dilihat melalui peningkatan aktivitas dan hasil belajar mengacu pada Kriteria Ketuntasan Minimum (KKM) mata pelajaran IPA untuk kompetensi dasar 5.2. (Menjelaskan pesawat sederhana yang dapat membuat pekerjaan lebih mudah dan lebih cepat) yang telah ditentukan oleh sekolah diawal tahun pelajaran 2016/2017 yaitu sebesar 60,00 .

\section{HASIL DAN PEMBAHASAN Pratindakan}

Sebelum memberikan tindakan, guru mengadakan tes penjajakan terlebih dahulu pada siswa. Hasil belajar siswa berdasarkan tes penjajakan yang telah dilakukan disajikan pada Tabel 1.

Tabel 1 Hasil tes penjajakan

\begin{tabular}{cllll}
\hline No & \multicolumn{1}{c}{ Nama Siswa } & KKM & Nilai & \multicolumn{1}{c}{ Keterangan } \\
\hline 1 & Amih Tahul Fikri & 60,00 & 60,00 & Tuntas \\
2 & Anief Irawan & 60,00 & 60,00 & Tuntas \\
3 & Dendi Sefri Adinata & 60,00 & 50,00 & Tidak Tuntas \\
4 & Dina Mardiana & 60,00 & 40,00 & Tidak Tuntas \\
5 & Elsa Yuliatami & 60,00 & 30,00 & Tidak Tuntas \\
6 & Egi Zaemansyah & 60,00 & 70,00 & Tuntas \\
7 & Hafiszon & 60,00 & 30,00 & Tidak Tuntas \\
8 & Intan Seprima Dewi & 60,00 & 40,00 & Tidak Tuntas \\
9 & Irdan Juni Yanda & 60,00 & 10,00 & Tidak Tuntas
\end{tabular}




\begin{tabular}{llccl}
10 & Joni Amsar & 60,00 & 60,00 & Tuntas \\
11 & Laela Asturi & 60,00 & 60,00 & Tuntas \\
12 & Pemen Rahmat Pratama & 60,00 & 50,00 & Tidak Tuntas \\
13 & Rika Anggraini & 60,00 & 50,00 & Tidak Tuntas \\
14 & Ramadhani & 60,00 & 60,00 & Tuntas \\
15 & Rinaldi Pratama & 60,00 & 40,00 & Tidak Tuntas \\
16 & Rafli Pramana & 60,00 & 30,00 & Tidak Tuntas \\
17 & Siti Zaleha & 60,00 & 40,00 & Tidak Tuntas \\
18 & Uhsin Mawadi & 60,00 & 30,00 & Tidak Tuntas \\
19 & Veni Zuldarti & 60,00 & 60,00 & Tuntas \\
20 & Wedi Tristianto & 60,00 & 70,00 & Tuntas \\
& Nilai Tertinggi & & 70,00 & \\
& Nilai Terendah & & 10,00 & \\
& Nilai Rata-Rata & & 47,50 & \\
& Ketuntasan Belajar & & $45,00 \%$ & \\
\hline
\end{tabular}

Hasil penelitian yang disajikan pada Tabel 1 menunjukkan bahwa nilai terendah siswa mengenai pemahaman konsep sebesar 10,00, sedangkan nilai tertingginya adalah sebesar 70,00 dengan nilai rata-rata sebesar 47,50. Nilai rata-rata ini masih termasuk dalam kategori rendah. Siswa yang mendapatkan nilai lebih besar dari KKM berjumlah 9 orang dengan persentase ketuntasan belajar siswa sebesar $45,00 \%$. Masalah yang dihadapi siswa adalah siswa tidak memahami konsep dengan baik sehingga siswa kesulitan mengisi soal dan berdampak pada rendahnya hasil belajar siswa. Dengan demikian, perlu adanya pemberian tindakan untuk mengatasi masalah tersebut.

\section{Siklus I}

Kegiatan penelitian pada siklus I dilaksanakan pada hari Selasa,7 Februari 2017 (Pertemuan ke-1 Siklus I), hari Selasa, 9 Februari 2017 (Pertemuan ke-2 Siklus I), dan hari Selasa, 14 Februari 2017 (Evaluasi Hasil Belajar Siklus I). Kegiatan penelitian pada siklus I terdiri atas perencanaan, pelaksanaan, pengamatan, dan refleksi.

Kegiatan pertama dalam Siklus I adalah perencanaan. Kegiatan perencanaan terdiri atas: menetapkan materi yang akan diajarkan, menyusun Rencana Pelaksanaan
Pembelajaran (RPP), menyusun prosedur untuk melakukan percobaan, dan melakukan uji coba pada percobaan yang akan dilaksanakan untuk menguji ketepatan proses dan hasilnya, menyiapkan alat dan bahan yang dibutuhkan untuk melakukan percobaan, menyiapkan alat evaluasi (lembar kerja siswa, lembar observasi aktivitas siswa, dan soal tes objektif).

Kegiatan kedua dalam Siklus I adalah pelaksanaan. Penelitian tindakan kelas dilakukan pada pembelajaran IPA khususnya pada materi pesawat sederhana.Materi yang disampaikan dalam siklus I adalah bagian dari pesawat sederhana yaitu pengungkit (pertemuan ke1 Siklus I) dan bidang miring (pertemuan ke-2 Siklus I). Kegiatan dilaksanakan dalam tiga tahap yaitu kegiatan awal, kegiatan inti, dan kegiatan akhir. Kegiatan Awal, terdiri atas: guru mengucapkan salam dan menanyakan keadaan siswa, guru mengecek kehadiran siswa secara klasikal, guru menyampaikan tujuan pembelajaran, guru menyampaikan skenario pembelajaran yang akan dilaksanakan. Kegiatan inti, terdiri atas: guru menjelaskan prosedur dalam melakukan percobaan, siswa melakukan percobaan secara berkelompok, guru membantu, membimbing, dan mengawasi siswa selama kegiatan percobaan 
berlangsung, siswa membuat laporan tentang percobaan, guru dan siswa mendiskusikan hasilpercobaan, dan siswa membersihkan dan menyimpan alat dan bahan yang digunakan dalam percobaan. Kegiatan penutup, terdiri atas: guru bersama siswa membuat kesimpulan pembelajaran, guru menyampaikan gambaran materi pelajaran selanjutnya, dan guru menyampaikan pesan moral. Pada akhir siklus, guru melakukan evaluasi hasil belajar siklus I.

Kegiatan ketiga dalam Siklus I adalah pengamatan. Kegiatan pengamatan dilakukan dengan cara mengamati aktivitas siswa selama melakukan kegiatan percobaan dan mencatat kejadian-kejadian yang terjadi selama pelaksanaan kegiatan pembelajaran. Hasil pengamatan menunjukkan bahwa siswa mendengarkan penjelasan dari guru selama kegiatan pembelajaran. Siswa mengajukan pertanyaan mengenai hal-hal yang tidak dipahaminya baik saat guru menjelaskan maupun saat melakukan percobaan, siswa mampu bekerja secara berkelompok. Akan tetapi, masih ada anggota kelompok yang tertarik dengan kegiatan yang dilakukan oleh kelompok lain. Siswa dapat melaksanakan percobaan sesuai dengan prosedur yang telah diberikan. Akan tetapi, masih ditemukan juga siswa yang tidak terlibat aktif dalam melaksanakan kegiatan percobaan. Ketika melaksanakan kegiatan percobaan, siswa juga masih bergantung dengan instruksi lisan dari guru. Siswa telah membersihkan dan menyimpan alat dan bahan yang telah digunakan dalam percobaan. Akan tetapi, masih terdapat siswa yang membersihkan dan menyimpan alat dan bahan jika diingatkan dan dilihat oleh guru. Ketika ditanya mengenai hasil percobaan, siswa saling tunjuk dengan anggota kelompoknya untuk menyampaikan hasil percobaan. Hal ini menunjukkan bahwa siswa masih belum berani untuk menyampaikan hasil percobaan. Hasil pengamatan aktivitas belajar siswa pada Siklus I disajikan pada Tabel 2.

Tabel 2 Hasil pengamatan aktivitas belajar siswa pada akhir Siklus I

\begin{tabular}{clcr}
\hline No & \multicolumn{1}{c}{ Aspek Pengamatan } & Jumlah & Persentase \\
\hline 1 & Siswa mendengarkan penjelasan guru & 20 & $100,00 \%$ \\
2 & Siswa mengajukan pertanyaan & 8 & $40,00 \%$ \\
3 & Siswa bekerja sama dalam kelompok & 10 & $50,00 \%$ \\
4 & Siswa dapat melakukan kegiatan percobaan & 10 & $50,00 \%$ \\
5 & Siswa membersihkan dan menyimpan alat dan bahan yang & 9 & $45,00 \%$ \\
& telah digunakan dalam percobaan & & \\
6 & Siswa dapat menyampaikan hasil percobaan & 5 & $25,00 \%$ \\
\hline
\end{tabular}

Hasil yang disajikan pada Tabel 2 menunjukkan bahwa siswa telah mampu mendengar penjelasan yang diberikan oleh guru. Akan tetapi, siswa kurang aktif dalam mengajukan pertanyaan. Hal ini mengindikasikan bahwa anak memiliki rasa ingin tahu yang rendah. Dengan demikian, guru perlu memberikan motivasi untuk meningkatkan rasa ingin tahu anak. Selain itu, guru juga perlu melakukan pendekatan secara pribadi dengan anak karena mungkin anak tidak mengajukan pertanyaan karena anak tidak berani atau belum mengerti mengenai hal-hal yang akan dilakukan. Hasil pengamatan juga menunjukkan bahwa siswa telah mampu bekerja secara berkelompok. Meskipun demikian, masih terdapat siswa yang mengunjungi meja kerja kelompok yang lain. Hal ini perlu diperhatikan juga oleh guru supaya siswa fokus dengan pekerjaan kelompoknya dan bekerja sama untuk menyelesaikan pekerjaan kelompoknya.

Hasil pengamatan juga menunjukkan bahwa siswa telah melakukan pekerjaan dengan mengikuti prosedur yang diberikan. 
Akan tetapi, masih terdapat siswa yang tidak terlibat secara aktif dalam melakukan percobaan. Siswa tersebut hanya melihat apa yang dilakukan teman sekelompoknya. Guru perlu melakukan pengawasan saat siswa melakukan percobaan dan apabila menemukan siswa yang tidak aktif dalam kegiatan percobaan, guru dapat mendorong siswa untuk melakukan percobaan untuk menambah pengetahuan berdasarkan pengalaman. Selain itu, hasil penelitian juga menemukan bahwa tidak semua siswa membersihkan dan menyimpan kembali alat dan bahan yang telah digunakan. Hanya terdapat satu atau dua orang siswa perempuan dalam setiap kelompok yang bersedia membersihkan dan menyimpan alat dan bahan yang telah digunakan. Masalah yang juga ditemukan oleh guru adalah siswa masih belum berani menyampaikan hasil percobaan yang telah dilakukan. Siswa takut hasil yang diperoleh oleh kelompoknya salah. Oleh karenanya, guru diharapkan dapat meningkatkan kepercayaan diri siswa dengan cara memberikan motivasi.

Selanjutnya, hasil evaluasi hasil belajar siswa pada Siklus I disajikan pada Tabel 3.

Tabel 3 Hasil penelitian pada Siklus I

\begin{tabular}{clccl}
\hline No & \multicolumn{1}{c}{ Nama Siswa } & KKM & Nilai & \multicolumn{1}{c}{ Keterangan } \\
\hline 1 & Amih Tahul Fikri & 60,00 & 70,00 & Tuntas \\
2 & Anief Irawan & 60,00 & 70,00 & Tuntas \\
3 & Dendi Sefri Adinata & 60,00 & 60,00 & Tuntas \\
4 & Dina Mardiana & 60,00 & 50,00 & Tidak Tuntas \\
5 & Elsa Yuliatami & 60,00 & 50,00 & Tidak Tuntas \\
6 & Egi Zaemansyah & 60,00 & 80,00 & Tuntas \\
7 & Hafiszon & 60,00 & 40,00 & Tidak Tuntas \\
8 & Intan Seprima Dewi & 60,00 & 50,00 & Tidak Tuntas \\
9 & Irdan Juni Yanda & 60,00 & 30,00 & Tidak Tuntas \\
10 & Joni Amsar & 60,00 & 70,00 & Tuntas \\
11 & Laela Asturi & 60,00 & 80,00 & Tuntas \\
12 & Pemen Rahmat Pratama & 60,00 & 60,00 & Tuntas \\
13 & Rika Anggraini & 60,00 & 70,00 & Tuntas \\
14 & Ramadhani & 60,00 & 70,00 & Tuntas \\
15 & Rinaldi Pratama & 60,00 & 50,00 & Tidak Tuntas \\
16 & Rafli Pramana & 60,00 & 40,00 & Tidak Tuntas \\
17 & Siti Zaleha & 60,00 & 60,00 & Tuntas \\
18 & Uhsin Mawadi & 60,00 & 50,00 & Tidak Tuntas \\
19 & Veni Zuldarti & 60,00 & 70,00 & Tuntas \\
20 & Wedi Tristianto & 60,00 & 90,00 & Tuntas \\
& Nilai Tertinggi & & 90,00 & \\
& Nilai Terendah & & 30,00 & \\
& Nilai Rata-Rata & 60,50 & \\
& Ketuntasan Belajar & $60,00 \%$ & \\
\hline
\end{tabular}

Hasil penelitian yang disajikan pada Tabel 3 menunjukkan bahwa nilai terendah siswa mengenai pemahaman tentang konsep pesawat sederhana pada mata pelajaran IPA adalah sebesar 30,00 dan nilai tertinggi siswa mengenai pemahaman tentang konsep pesawat sederhana pada mata pelajaran IPA adalah sebesar 90,00. Nilai rata-rata yang diperoleh siswa adalah sebesar 60,5. Niai rata-rata yang diperoleh siswa setelah diberikan tindakan (pembelajaran dengan metode eksperimen) 
mengalami peningkatan. Nilai rata-rata siswa pada pratindakan sebesar 47,50 meningkat menjadi 60,50. Hasil ini mengindikasikan bahwa penggunaan metode eksperimen dalam kegiatan pembelajaran IPA khususnya pada materi pesawat sederhana telah mulai menunjukkan keberhasilan. Dengan demikian, penggunaan metode ini perlu dilanjutkan ke siklus berikutnya. Selain peningkatan rata-rata, guru juga melihat terjadinya peningkatan dalam aspek ketuntasan belajar. Ketuntasan belajar paa siklus I sebesar $60,00 \%$ yang meningkat dibandingkan dengan ketuntasan belajar saat pratindakan yang hanya sebesar $45,00 \%$.

Kegiatan keempat dalam Siklus I adalah refleksi. Kegiatan refleksi terdiri atas: menganalisis data hasil pelaksanaan tindakan, mengevaluasi pelaksanaan tindakan yang telah dilakukan pada siklus I, dan menyusun rencanatindakan untuk siklus II. Refleksi dari hasil penelitian adalah sebagai berikut:

1. Memperbaiki perangkat pembelajaran untuk meningkatkan keaktifan siswa dalam kegiatan pembelajaran.

2. Mendampingi siswa dalam bekerja secara berkelompok

3. Melakukan evaluasi pekerjaan siswa

4. Memotivasi siswa agar berani menyampaikan hasil percobaannya.

5. Merumuskan tindakan siklus II berdasarkan temuan pada siklus I.

\section{Siklus II}

Kegiatan penelitian pada siklus II dilaksanakan pada hari Selasa, 21 Februari 2017 (Pertemuan ke-1 Siklus II), hari Selasa, 23 Februari 2017(Pertemuan ke-2 Siklus II), dan hari Selasa, 28 Februari 2017(Evaluasi Hasil Belajar Siklus II). Kegiatan penelitian pada siklus II terdiri atas perencanaan, pelaksanaan, pengamatan, dan refleksi.

Kegiatan pertama dalam Siklus II adalah perencanaan. Kegiatan perencanaan terdiri atas: menetapkan materi yang akan diajarkan, menyusun Rencana Pelaksanaan Pembelajaran (RPP), menyusun prosedur untuk melakukan percobaan, dan melakukan uji coba pada percobaan yang akan dilaksanakan untuk menguji ketepatan proses dan hasilnya, menyiapkan alat dan bahan yang dibutuhkan untuk melakukan percobaan, menyiapkan alat evaluasi (lembar kerja siswa, lembar observasi aktivitas siswa, dan soal tes objektif).

Kegiatan kedua dalam Siklus II adalah pelaksanaan. Penelitian tindakan kelas dilakukan pada pembelajaran IPA khususnya pada materi pesawat sederhana.Materi yang disampaikan dalam siklus II adalah bagian dari pesawat sederhana yaitu katrol (pertemuan ke-1 Siklus II) dan roda berporos (pertemuan ke-2 Siklus II). Kegiatan dilaksanakan dalam tiga tahap yaitu kegiatan awal, kegiatan inti, dan kegiatan akhir. Kegiatan Awal, terdiri atas: guru mengucapkan salam dan menanyakan keadaan siswa, guru mengecek kehadiran siswa secara klasikal, guru menyampaikan tujuan pembelajaran, guru menyampaikan skenario pembelajaran yang akan dilaksanakan. Kegiatan inti, terdiri atas: guru menjelaskan prosedur dalam melakukan percobaan, siswa melakukan percobaan secara berkelompok, guru membantu, membimbing, dan mengawasi siswa selama kegiatan percobaan berlangsung, siswa membuat laporan tentang percobaan, guru dan siswa mendiskusikan hasil percobaan, dan siswa membersihkan dan menyimpan alat dan bahan yang digunakan dalam percobaan. Kegiatan penutup, terdiri atas: guru bersama siswa membuat kesimpulan pembelajaran, guru menyampaikan gambaran materi pelajaran selanjutnya, dan guru menyampaikan pesan moral. Pada akhir siklus, guru melakukan evaluasi hasil belajar siklus II.

Kegiatan ketiga dalam Siklus II adalah pengamatan. Kegiatan pengamatan dilakukan dengan cara mengamati aktivitas 
siswa selama melakukan kegiatan percobaan dan mencatat kejadian-kejadian yang terjadi selama pelaksanaan kegiatan pembelajaran. Hasil pengamatan menunjukkan bahwa siswa mendengarkan penjelasan dari guru selama kegiatan pembelajaran. Jumlah siswa yang mengajukan pertanyaan mengenai hal-hal yang tidak dipahaminya bertambah. Siswa mulai fokus bekerja dengan kelompoknya. Setelah mendengar penjelasan guru, siswa langsung memulai melaksanakan percobaan dengan mengikuti prosedur yang telah diberikan di lembar kerja siswa. Beberapa siswa telah mampu untuk melakukan percobaan dengan mandiri dan siswa yang mampu tersebut juga memimpin anggota kelompok yang lain dalam melakukan percobaan. Setelah melakukan percobaan, siswa membersihkan dan menyimpan alat dan bahan yang telah digunakan tanpa harus diingatkan dan dilihat oleh guru. Ketika ditanya mengenai hasil percobaan, siswa sudah mulai mengajukan dirinya untuk menjelaskan hasil percobaan yang telah dilakukannya. Hasil pengamatan aktivitas belajar siswa pada Siklus I disajikan pada Tabel 4.

Tabel 4 Hasil pengamatan aktivitas belajar siswa pada akhir Siklus II

\begin{tabular}{clcr}
\hline No & \multicolumn{1}{c}{ Aspek Pengamatan } & Jumlah & Persentase \\
\hline 1 & Siswa mendengarkan penjelasan guru & 20 & $100,0 \%$ \\
2 & Siswa mengajukan pertanyaan & 15 & $75,0 \%$ \\
3 & Siswa bekerja sama dalam kelompok & 20 & $100,0 \%$ \\
4 & Siswa dapat melakukan kegiatan percobaan & 18 & $90,0 \%$ \\
5 & Siswa membersihkan dan menyimpan alat dan bahan yang & 20 & $100,0 \%$ \\
& telah digunakan dalam percobaan & & \\
6 & Siswa dapat menyampaikan hasil percobaan & 14 & $70,0 \%$ \\
\hline
\end{tabular}

Hasil yang disajikan pada Tabel 4 menunjukkan bahwa siswa telah mampu mendengar penjelasan yang diberikan oleh guru, siswa telah mampu bekerja secara berkelompok, dan siswa membersihkan dan menyimpan kembali alat dan bahan yang telah digunakan. Selain itu, jumlah siswa yang aktif dalam mengajukan pertanyaan juga meningkat. Meskipun demikian, masih terdapat siswa yang malumalu untuk bertanya. Siswa tersebut memanggil guru dan ketika guru mendekat, siswa tersebut baru berani menyampaikan pertanyaannya. Dengan demikian, guru perlu memotivasi siswa untuk meningkatkan kepercayaan dirinya. Hasil pengamatan juga menunjukkan bahwasetelah mendengar penjelasan guru, siswa langsung memulai melaksanakan percobaan dengan mengikuti prosedur yang telah diberikan di lembar kerja siswa. Beberapa siswa telah mampu untuk melakukan percobaan dengan mandiri dan siswa yang mampu tersebut juga memimpin anggota kelompok yang lain dalam melakukan percobaan. Hasil penelitian juga menemukan bahwamasih terdapat siswa yang perlu dituntun dalam menemukan hasil percobaan. Ketidakmampuan siswa mengenai hasil penelitian berdampak juga pada kurangnya kepercayaan diri siswa untuk menyampaikan hasil percobaannya. Dengan demikian, guru perlu memastikan setiap siswa dalam kelompok mengetahui hasil dari kegiatan yang telah dilakukan. Guru juga dapat meminta bantuan kepada setiap siswa yang pandai dalam kelompok untuk membantu siswa yang belum bisa dalam memahami hasil percobaan. Selanjutnya, hasil evaluasi hasil belajar siswa pada Siklus II disajikan pada Tabel 5 . 
Tabel 5 Hasil penelitian pada Siklus II

\begin{tabular}{cllcl}
\hline No & \multicolumn{1}{c}{ Nama Siswa } & KKM & Nilai & \multicolumn{1}{c}{ Keterangan } \\
\hline 1 & Amih Tahul Fikri & 60,00 & 90,00 & Tuntas \\
2 & Anief Irawan & 60,00 & 80,00 & Tuntas \\
3 & Dendi Sefri Adinata & 60,00 & 80,00 & Tuntas \\
4 & Dina Mardiana & 60,00 & 70,00 & Tuntas \\
5 & Elsa Yuliatami & 60,00 & 60,00 & Tuntas \\
6 & Egi Zaemansyah & 60,00 & 100,00 & Tuntas \\
7 & Hafiszon & 60,00 & 50,00 & Tidak Tuntas \\
8 & Intan Seprima Dewi & 60,00 & 70,00 & Tuntas \\
9 & Irdan Juni Yanda & 60,00 & 50,00 & Tidak Tuntas \\
10 & Joni Amsar & 60,00 & 80,00 & Tuntas \\
11 & Laela Asturi & 60,00 & 90,00 & Tuntas \\
12 & Pemen Rahmat Pratama & 60,00 & 70,00 & Tuntas \\
13 & Rika Anggraini & 60,00 & 80,00 & Tuntas \\
14 & Ramadhani & 60,00 & 80,00 & Tuntas \\
15 & Rinaldi Pratama & 60,00 & 70,00 & Tuntas \\
16 & Rafli Pramana & 60,00 & 50,00 & Tidak Tuntas \\
17 & Siti Zaleha & 60,00 & 70,00 & Tuntas \\
18 & Uhsin Mawadi & 60,00 & 70,00 & Tuntas \\
19 & Veni Zuldarti & 60,00 & 90,00 & Tuntas \\
20 & Wedi Tristianto & 60,00 & 100,00 & Tuntas \\
& Nilai Tertinggi & & 100,00 & \\
& Nilai Terendah & & 50,00 & \\
& Nilai Rata-Rata & & 75,00 & \\
& Ketuntasan Belajar & & $85,00 \%$ & \\
\hline
\end{tabular}

Hasil penelitian yang disajikan pada Tabel 5 menunjukkan bahwa nilai terendah siswa mengenai pemahaman tentang konsep pesawat sederhana pada mata pelajaran IPA adalah sebesar 50,00 dan nilai tertinggi siswa mengenai pemahaman tentang konsep pesawat sederhana pada mata pelajaran IPA adalah sebesar 100,00 dengan nilai rata-rata sebesar 75,00. Niai rata-rata yang diperoleh siswa pada siklus II mengalami peningkatan dibandingkan dengan hasil dari siklus I. Nilai rata-rata siswa pada Siklus I sebesar 60,50 meningkat menjadi 75,00. Hasil ini mengindikasikan bahwa penggunaan metode eksperimen dalam kegiatan pembelajaran IPA khususnya pada materi pesawat sederhana telah berhasil meningkatkan hasil belajar siswa. Selain peningkatan nilai rata-rata, guru juga melihat terjadinya peningkatan dalam aspek ketuntasan belajar. Ketuntasan belajar pada siklus II sebesar $85,00 \%$. Hasil ini lebih besar dibandingkan dengan ketuntasan belajar saat Siklus I yaitu sebesar 60,00\%.

Kegiatan keempat dalam siklus II adalah refleksi. Refleksi dari hasil penelitian adalah sebagai berikut:

1. Metode eksperimen membawa perubahan baik pada aktivitas siswa maupun dalam hal hasil belajar siswa. Keterlibatan siswa secara langsung dalam kegiatan pembelajaran memudahkan siswa dalam memahami konsep yang diajarkan. Dengan demikian, metode ini dapat menjadi alternative dalam kegiatan pembelajaran IPA.

2. Hasil penelitian menunjukkan bahwa masih terdapat siswa yang mengalami kesulitan dalam menyampaikan hasil dan juga mengajukan pertanyaan. Hal ini dapat terjadi karena kurang percaya 
diri, dengan demikian guru perlu mendorong dan memberikan motivasi pada siswa untuk berani tampil di depan kelas.

3. Guru juga perlu melakukan evaluasi diri untuk menemukan masalah pembelajaran yang berasal dari faktor guru. Guru diharapkan juga dapat mengurangi masalah yang disebabkan dari guru sendiri. Hal ini perlu dilakukan untuk meningkatkan kualitas pembelajaran.

4. Hasil penelitian ini menjadi acuan dalam menyusun perangkat pembelajaran untuk materi selanjutnya.

\section{Analisis Hasil Belajar Siswa}

Pemahaman siswa mengenai konsep pesawat sederhana pada mata pelajaran IPA dilihat berdasarkan hasil belajar siswa. Hasil belajar siswa dinilai dari nilai rata- rata kelas dan ketuntasan belajar siswa. Hasil penelitian memperlihatkanbahwa nilai rata-rata kelas yang pada saat pratindakan hanya sebesar 47,5 meningkat menjadi 60,5 pada akhir siklus I dan kembali meningkat menjadi 75,0 pada akhir siklus II. Apabila hasil pada akhir siklus II dibandingkan dengan hasil pada saat pratindakan maka diperoleh selisih sebesar 27,5 point. Selain peningkatan nilai rata-rata kelas, ketuntasan belajar siswa juga meningkat. Ketuntasan belajar siswa pada saat pratindakan hanya sebesar $45,0 \%$ meningkat menjadi $60,0 \%$ pada akhir siklus I dan kembali meningkat menjadi $85,0 \%$ pada akhir siklus II. Apabila hasil pada akhir siklus II dibandingkan dengan hasil pada saat pratindakan maka diperoleh selisih sebesar 40,0\%. Rekapitulasi hasil belajar siswa pada saat pratindakan, siklus I, dan siklus II disajikan pada Gambar 1.

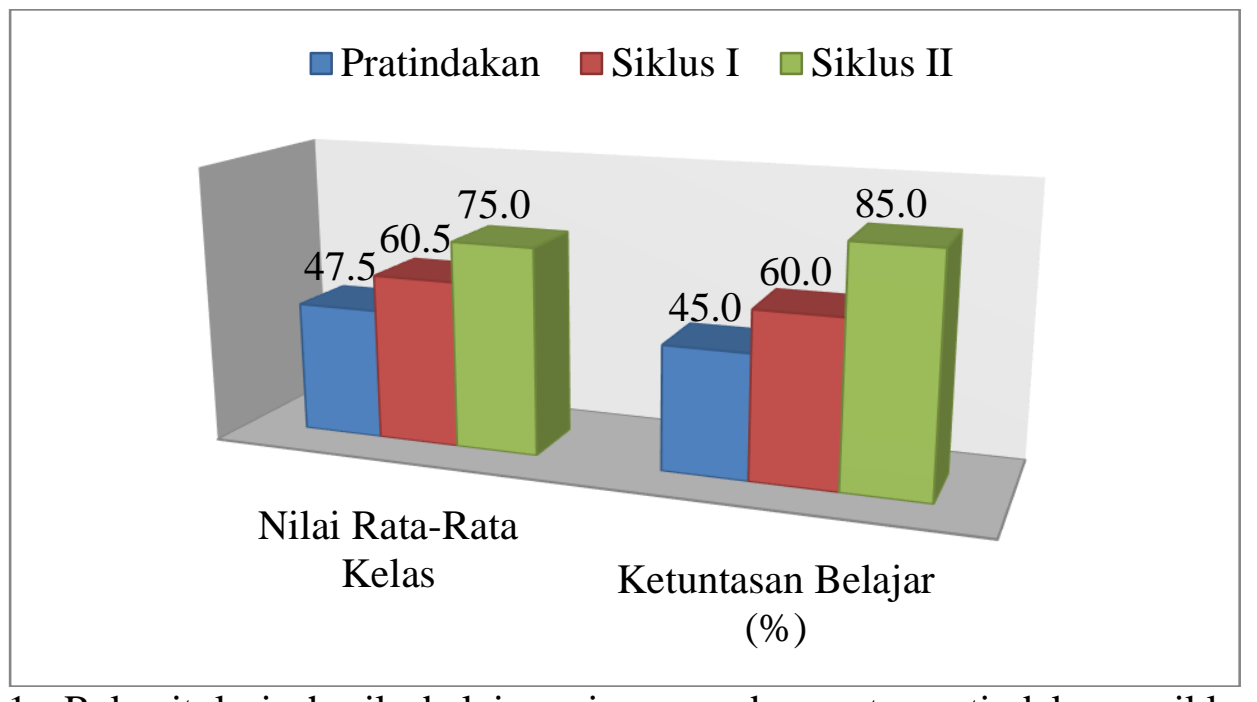

Gambar 1 Rekapitulasi hasil belajar siswa pada saat pratindakan, siklus I, dan siklus II

Hasil penelitian menunjukkan bahwa terjadi peningkatan hasil belajar siswa dari sebelum dilaksanakan tindakan sampai dengan setelah dilaksanakan tindakan (siklus I dan siklus II). Berdasarkan hasil penelitian, dapat disimpulkan bahwa penggunaan metode eksperimen dapat meningkatkan pemahaman siswa tentang konsep pesawat sederhana pada mata pelajaran IPA kelas V SDN. No. 033/XI
Tanjung Muda tahun pelajaran 2016/2017. Hasil penelitian ini mendukung hasil penelitianAsmawir (2016) yang menemukan bahwa metode eksperimen dapat meningkatkan hasil belajar siswapada materi pesawat sederhana pada mata pelajaran IPA Kelas V SDN No. 3 Siboang. Hasil penelitian ini juga mendukung temuan Rosilahwati (2016) bahwa metode eksperimen dapat 
meningkatkan hasil belajar siswa mata pelajaran IPA sub pokok bahasan pesawat sederhana di Kelas V MI Negeri Watuagung Tahun Pelajaran 2015/2016. Selain itu, hasil penelitian ini juga mendukung temuan Maria (2014) bahwa penggunaan metode eksperimen dapat meningkatkan hasil belajar siswa kelas $\mathrm{V}$ Sdn 43 Tapis Tembawang.

Metode eksperimen merupakan salah satu metode yang cocok digunakan dalam mata pelajaran IPA. Menurut Khotimah (2015), metode eksperimen berpengaruh terhadap keterampilan proses dan hasil belajar IPA pada siswa Sekolah Dasar. Dengan demikian, penggunaan metode eksperimen dapat meningkatkan kualitas hasil belajar IPA yang juga akan mendorong meningkatnya prestasi siswa dalam mata pelajaran IPA. Hal ini diperkuat oleh temuan Habiby (2016) bahwa metode ekperimen dianggap metode yang efektif untuk meningkatkan prestasi belajar siswa pada mata pelajaran IPA di Sekolah Dasar. Oleh karenanya, metode eksperimen menjadi pilihan guru yang bertujuan untuk meningkatkan hasil belajar siswa. Rahayu (2013) juga telah membuktikan bahwa penggunaan metode eksperimen dapat meningkatkan hasil belajar IPA materi pengaruh perubahan lingkungan fisik terhadap daratan siswa kelas IV SD N 2 Bakalan KrapyakTahun 2012/2013. Tidak hanya penelitian tindakan kelas yang telah membuktikan pengaruuh dari metode eksperimen terhadap hasil belajar siswa pada mata pelajaran IPA. Penelitian eksperimen yang dilakukan oleh Pranolo (2013) juga telah membuktikan bahwa penggunaan metode eksperimen berpengaruh signifikan terhadap hasil belajar siswa kelas $\mathrm{V}$ pada mata pelajaran IPA di SDN Sukomulyo Ngaglik Sleman.

\section{SIMPULAN}

Penggunaan metode eksperimen dapat meningkatkan pemahaman siswa tentang konsep pesawat sederhana pada mata pelajaran IPA kelas V SDN.No.033/XI Tanjung Muda tahun pelajaran 2016/2017. Penggunaan metode eksperimen meningkatkan aktivitas dan hasil belajar siswa pada mata pelajaran IPA. Peningkatan aktivitas belajar siswa terlihat dari bertambahnya persentase siswa yangmengajukan pertanyaan, bekerja sama dalam kelompok, mampu melakukan kegiatan percobaan secara mandiri, membersihkan dan menyimpan alat dan bahan yang telah digunakan dalam percobaan, dan menyampaikan hasil percobaan. Peningkatan juga terjadi pada hasil belajar yang diperoleh siswa yang dapat dilihat dari peningkatan nilai ratarata kelas dan capaian ketuntasan belajar siswa sebelum dilakukan tindakan dan setelah dilaksanakan tindakan (siklus I dan siklus II).

Berdasarkan temuan penelitian, pendidik diharapkan dapat menggunakan metode eksperimensebagai alternatif dalam meningkatkan aktivitas dan hasil belajar siswapada mata pelajaran IPA. Pendidik diharapkan juga untuk menambah pengetahuannya melalui kegiatan pelatihan. Pendidik diharapkan juga dapatmenggunakan model, pendekatan, strategi, metode, dan teknik pembelajaran yang variatif dan inovatif. Penelitian ini juga menyarankan kepada pendidik untuk memecahkan permasalahan pembelajaran di kelas melalui kegiatan Penelitian Tindakan Kelas.

\section{DAFTAR PUSTAKA}

Ambai, U. H. A., Said, I., \& Ratman. (2014). Penggunaan KIT IPA Untuk Meningkatkan Hasil Belajar Siswa Pada Konsep Pesawat Sederhana di Kelas V SDN Potil Pololoba Kecamatan Banggai Kabupaten Banggai Kepulauan. Jurnal Kreatif Tadulako Online, Vol. 2 No. 3,78-88

Adji, A. G., Rede, A., \& Mestawaty, A. A. (2016). Meningkatkan Hasil Belajar Siswa Pada Pembelajaran IPA Kelas V Melalui Model Kooperatif Tipe 
STAD di SD Inpres 1 Ongka. Jurnal Kreatif Tadulako Online, Vol. 4 No. 5, 25-39.

Asmawir. (2016). Upaya Meningkatkan Hasil Belajar Siswa Melalui Metode Eksperimen Pada Materi Pesawat Sederhana Pada Mata Pelajaran IPA Kelas V SDN No. 3 Siboang. Jurnal Kreatif Tadulako Online, Vol. 4 No. 1, 183-198.

Djamarah, S. B. (2011). Psikologi Belajar. Jakarta: Rineka Cipta.

Habiby, M. (2016). Peningkatan Prestasi Belajar IPA Melalui Metode Eksperimen. Jurnal Pendidikan Guru Sekolah Dasar Edisi 36 Tahun ke-5.

Irham, M., \& Wiyani, N. A. (2013). Psikologi Pendidikan: Teori dan Aplikasi dalam Proses Pembelajaran. Yogyakarta: Ar Ruzz Media.

Khotimah, A. (2015). Pengaruh Penggunaan Metode Eksperimen Terhadap Keterampilan Proses Dan Hasil Belajar IPA Siswa Kelas IV SD Negeri Gunungsaren Bantul. Yogyakarta: Program Studi Pendidikan Guru Sekolah Dasar, Jurusan Pendidikan Pra Sekolah Dan Sekolah Dasar, Fakultas Ilmu Pendidikan, Universitas Negeri Yogyakarta

Maria, L. (2014). Penggunaan Metode Eksperimen Untuk Meningkatkan Hasil Belajar Siswa Kelas V Sdn 43 Tapis Tembawang [Skripsi]. Pontianak: Program Studi Pendidikan Guru Sekolah Dasar, Jurusan Pendidikan Dasar, Fakultas Keguruan dan Ilmu Pendidikan, Universitas Tanjungpura.

Megawati. (2016). Penerapan Model Pembelajaran Explicit Instruction Untuk Meningkatkan Hasil Belajar Siswa Pada Mata Pelajaran IPA di Kelas V SDN Ginunggung Tolitoli. Jurnal Kreatif Tadulako Online, Vol. 4 No. 10, 126-141.
Pranolo, H. H. (2013). Pengaruh Penggunaan Metode Eksperimen Terhadap Hasil Belajar Siswa Kelas V Pada Mata Pelajaran IPA SDN Sukomulyo Ngaglik Sleman. Yogyakarta: Program Studi Pendidikan Guru Sekolah Dasar, Jurusan Pendidikan Pra Sekolah dan Sekolah Dasar, Fakultas Ilmu Pendidikan, Universitas Negeri Yogyakarta.

Rahayu, P. D. (2013). Penggunaan Metode Eksperimen untuk Meningkatkan Hasil Belajar IPA Materi Pengaruh Perubahan Lingkungan Fisik terhadap Daratan Siswa Kelas IV SD N 2 Bakalan Krapyak Tahun 2012/2013 [Skripsi]. Pendidikan Guru Sekolah Dasar Fakultas Keguruan dan Ilmu Pendidikan Universitas Muria Kudus.

Rosilahwati, H. (2016). Peningkatan Hasil Belajar Siswa Mata Pelajaran IPA (Ilmu Pengetahuan Alam) Sub Pokok Bahasan Pesawat Sederhana Melalui Metode Eksperimen di Kelas V Mi Negeri Watuagung Tahun Pelajaran 2015/2016 [skripsi]. Purwokerto: Program Studi Pendidikan Guru Madrasah Ibtidaiyah, Jurusan Pendidikan Madrasah, Fakultas Tarbiyah Dan Ilmu Keguruan, Institut Agama Islam Negeri (IAIN) Purwokerto

Rukmia. (2016). Meningkatkan Hasil Belajar Siswa Melalui Model Pembelajaran Kooperatif Tipe Jigsaw Dalam Pembelajaran IPA Materi Pesawat Sederhana Di Kelas V SDN No. 1 Balukang II. Jurnal Kreatif Tadulako Online, Vol. 4 No. 1, 287-295.

Rusmono. (2012). Strategi Pembelajaran dengan Problem Based Learning itu Perlu. Bogor: Ghalia Indonesia.

Suak, R., Said, I., \& Paluin, Y. K. (2016). Meningkatkan Hasil Belajar IPA Tentang Konsep Pesawat Sederhana 
Melalui Metode Demonstrasi Pada Siswa Kelas V SD Inpres 2

Langaleso. Jurnal Kreatif Tadulako Online, Vol. 4 No. 6, 90-101.

Suprihatiningrum, J. 2014. Strategi Pembelajaran: Teori dan Aplikasi. Yogyakarta: Ar Ruzz Media.

Yamin HM. 2007. Desain Pembelajaran Berbasis Tingkat Satuan Pendidikan. Jakarta: Gaung Persada Press. 